\title{
ГЕРБАРТІАНСТВО І СОЦІАЛЬНА ПЕДАГОГІКА: ЗАБУТІ СТОРІНКИ
}

Н. О. Федчишин

\author{
ДВНЗ “Тернопільський держсавний медичнийуніверситет імені І. Я. Горбачевського МОЗ Украйни”
}

\section{HERBARTIANIS AND SOCIAL PEDAGOGY: HISTORICAL OUTLINE \\ N. O. Fedchyshyn}

\author{
SHEI "Ternopil State Medical University by I. Ya. Horbachevsky of MPH of Ukraine”
}

\begin{abstract}
У статті проаналізовано вплив ідей гербартіанства на соціальну педагогіку; розкрито зміст дискусійних питань соціальної педагогіки представниками цієї течії; з'ясовано, що гербартіанці запропонували педагогіку, яка окреслила форми індивідуальної організації навчання, зорієнтованої на релігію, мораль та національність.
\end{abstract}

The influence of Herbartian ideas on social pedagogy are analyzed, the content of disputable issues of social pedagogy are revealed by the representatives of this movement in the given article. There have been found that Herbartdisciples suggested pedagogy, which defined the forms of individual training, oriented towards religion, morality and nationality.

Вступ. Сьогодні продовжується етап модернізації освіти, визначаються пріоритетні стратегічні напрями, акцентується необхідність відповідності освітньої політики держави гуманістичній, особистісно і соціально зорієнтованій парадигмі освіти. Саме тому назріває необхідність пошуку зарубіжного педагогічного досвіду, зокрема німецькомовних країн (Німеччини та Австріі), які яскраво втілили передові ідеї європейської педагогічної думки й мали суттєвий вплив на становлення педагогічної науки. У зв'язку 3 цим цікавим для вивчення й аналізу є досвід гербартіанців (комплекс ідей, поглядів, концепцій, які відображають основні тенденції та сутність освітнього процесу).

В історіографії педагогіки малодослідженими є як гербартіанська педагогіка, так і соціальна педагогіка в контексті гербартіанства. До цього часу не було досліджень, які би відображали, як з другої половини XIX ст. і аж до часів Ваймарської республіки гербартіанство мало основний вплив на соціальну педагогіку. І тим не менше це аж ніяк не спричинилося до розв'язання цього питання. У шкільній педагогіці гербартіанство не брали до уваги і на противагу йому увели реформаторську педагогіку.

У праці "Соціально-педагогічне гербартіанство" К. Мюллєр порушив питання про взаємозв' язок між вченням гербартіанства та розумінням проблематики соціальної педагогіки з метою реконструкції педагогіки гербартіанців. В цілому такий проект дискусії був спрямований по-новому стимулювати інтерес до

(с) Н. О. Федчишин ставлення до соціальної педагогіки як складової соціальної роботи і педагогіки у різних формах, як-от шкільна педагогіка, спеціальна (лікувальна педагогіка) чи дошкільна. Відповідно до цього проект передбачав отримати відповіді щодо скороченого подання чи обмежень у педагогічному вченні гербартіанців та відкрити нові горизонти його практичного застосування. Такий проект був схвалений Німецьким науково-дослідницьким співтовариством (2009) (Deutsche Forschungsgemeinschaft (DFG)) і мав сприяти таким науковим пошукам. Тут слід назвати В. Шрьоєра (Wolfgang Schroer) (професора інституту соціальної педагогіки університету м. Гільдесгайм), Б. Доллінгера (Bernd Dollinger) (професора кафедри соціальної педагогіки університету м. Бамберг), К. Мюллєра (Carsten Muller) (професора інституту педагогіки м. Ольденбург) при підтримці членів спілки гербартіанців ("Herbart-Gesellschaft") P. Коріанд (Rotraud Coriand) та М. Вінклєра (Michael Winkler). Робота колективу базувалася на вже наявних дослідженнях у сфері історії соціальної педагогіки й вилилася у спільні наукові зустрічі-обговорення методичних та змістових проблематик. На дискусії були винесені такі спірні теми, як взаємозв' язок між соціально-теоретичними та соціально-науковими питаннями, шкільний статут, комбінації зі словом “соціальний”, як-от соціальне питання, соціальне виховання. Якісний аналіз, зорієнтований на наочність, слід було змінити зразковим (прикладним) аналізом програмних текстів, а науково-дослідницькі публікації доповнено використанням об'єктивної герменевтики (аналіз послідовності). На науково-практичній 
конференції з історії соціальної педагогіки та соціальної роботи у м. Ольтен (Швейцарія, 2007) було розпочато Б. Доллінгером (В. Dollinger), К. Мюллєром (C. Muller) та B. Шрьоєром (W. Schroer) вибірку та початковий аналіз відповідних текстів. У Німеччині активно розроблялася філософія освіти і соціальна педагогіка у гербартіанстві займала чільне місце. До вивчення цього питання зверталися Д. Беннер (D. Benner), В.-P. Вендт (W. R. Wendt), К. Гіллєнбранд (C. Hillenbrand), Б. Доллінгер (B. Dollinger), Р. Коріанд (R. Coriand), К. Мюллер (C. Muller), P. Ріссманн (R. Rissmann), Б. Швенк (B. Schwenk), В. Шрьоєр (W. Schroer) та ін.

Метою статті $€$ аналіз впливу гербартіанських ідей на соціальну педагогіку. Для розгляду даного питання слід виконати такі завдання:розкрити зміст дискусійних питань соціальної педагогіки представниками гербартіанської течії та з'ясувати, яку педагогіку запропонували гербартіанці для виокремлення форм індивідуальної організації навчання, зорієнтованої на релігію, мораль та національність.

Основна частина. Прогалини та скорочення у вченні гербартіанців $є$ тим суттєвішими, коли мова йде про історіографію соціальної педагогіки, але без аналізу гербартіанства. Наприкінці XIX ст. набули популярності різні соціальні та педагогічні реформаторські рухи. Представники гербартіанства відповідно заявили про значну кількість представників своєї течії, зацікавлених у дискусії питаннями соціальної педагогіки. Ця причина спровокувала значну кількість публікацій, дискусій у наукових журналах, колективних монографіях гербартіанців та їх прихильників. Були порушені такі спірні питання та позиції:

- гербартіанство як течія, яка бере свій початок від Й.-Ф. Гербарта, змогло визначити педагогіку домінуючою і диференціювати у XIX ст. (і не лише у Німеччині) ії як науку;

- питання про педагогічні журнали, педагогічні архіви, щорічники з наукової педагогіки й філософські журнали, журнали з філософії та педагогіки (К. Магер, Ф.-В. Дьорпфельд, А. Лінднер, О. Вільманн, В. Райн, Й. Трюпер).

У 1924 році В. Райн опублікував свою працю "Маркс чи Гербарт". Постановка такого питання В. Райном сколихнула на рубежі століть наукові кола 3 проблематики соціальної педагогіки. Противники науки про виховання, зорієнтованої на педагогіку Й.-Ф. Гербарта, не зрозуміли, яким чином вони відкрили шлях марксистській педагогіці та як відомі прихильники вчення Песталоцці, запровадженого у гербартіанській школі, відмовилися від гербартіансь- кої педагогіки [8]. Замість терміну “держава” у марксистській філософії виокремлюємо поняття “суспільство", яке передбачало подолати німецьке розуміння "держави”. На противагу цьому гербартіанська педагогіка пропонувала підстави для запобігання планомірній соціалізації освіти. В. Райн запропонував педагогіку, яка “може подати” форми індивідуальної організації навчання, зорієнтованої на релігію, мораль та національність [8].

В. Райн помітив соціалізуючу, атеїстичну, інтернаціональну, матеріалістичну педагогіку соціалістів, які намагалися увести пролетаріат і молодь у партійні догми. Його модель чітко схарактеризувала проблематику соціальної педагогіки. Економічний та соціальний розвиток, який супроводжувався крахом “старих патріархальних відносин", вивільнили навчання та виховання 3-під соціально-структурного впливу середнього класу, сім'ї, церкви, селянства. В. Райну імпонувала гербартіанська школа, освітні інституції якої гарантували виховання повноцінної моральної особистості, достойного громадянина держави [2]. Думки про успішність соціалізації навчання та виховання були для гербартіанця фатальними і не узгоджувалися 3 правлячим суспільством. 3 іншого боку В. Райн усвідомлював, що дискусії щодо соціалізації навчання і виховання не припинялися й соціальне формування та завдання навчання стали політичною справою. На цей час був попит на теорію, яка глибоко проникала у справу виховання, розвивала школу як освітню інституцію. Зрештою, мова йшла про те, щоб виявити соціальні заклади навчання й педагогічну перспективу з огляду на форми усуспільнення капіталістичного світу та сформулювати педагогічні прагнення соціальної педагогіки і соціальних реформ.

Педагоги намагалися розв'язувати завдання, де вимагалося розуміння застосування соціології у педагогіці з метою перевірки тогочасної педагогічної системи [3]. Р. Ріссманн переконував, що "педагогіка повинна стати у майбутньому і культурологією, і соціальною наукою" [9]. Під соціалізацією навчання розуміли формування для громадян, суспільства, держави освітніх інстанцій, вільних від “аристократії капіталу”, тобто визнання права на освіту.

Майже всі соціальні педагоги, у тому числі гербартіанець В. Райн, вказували на необхідність віднайти основу єдності у навчанні з метою об'єднання роздробленого суспільства. Вони не сумнівалися у тому, що сутність та фундамент німецької соціокультури можна віднайти в ідеалістичній філософії навчання. Водночас вони визнавали, що соціокультурна дійсність капіталістичного способу життя приносить 
у жертву соціокультурне спрямування німецької нації та освіти. Саме у цей час спостерігаємо розходження у думках навколо питання “тенденцій соціалізації” у педагогіці [4]. Розуміння застосування навчання та освітніх реалій спровокувало полеміку навколо соціальної педагогіки. Помітними були пропозиції щодо освіти на рівні держави.

В. Райн, як учень гербартіанців К.-Ф. Стоя та Т. Ціллєра, і надалі своєю збалансованою та систематизованою науковою роботою намагався розвивати й поширювати вчення Гербарта. "Енциклопедичний посібник з педагогіки” В. Райна став основою неогербартіанства й сприяв закріпленню гербартіанськихідей у німецькій школі. Водночас В. Райн не міг зарадити початковій відмові від застосування гербартіанських ідей. “Кристалізація” дебатів довкола гербартіанства та початок спаду популяризації педагогіки цієї течії розпочалися наприкінці XIX ст. [10]. Зростаюча модернізація економіки, соціальні вибухи вимагали від критиків гербартіанства розуміння наукових основ педагогічної науки. У цьому зв' язку, піддане нищівній критиці експериментальною педагогікою та психологією, вчення про методи навчання гербартіанства спричинило “боротьбу заГербарта" та його школу (виступили провідні представники народної школи (П. Наторп, П. Бергеманн)). Публікацією у 1924 році праці "Маркс чи Гербарт" В. Райн намагався закцентувати увагу на вагомості гербартіанських ідей у німецькій педагогіці. Він ще мав сподівання, що молода Ваймерська республіка потребувала саме таких педагогічних поглядів та не зважатиме на критику гербартіанства в останні роки й тим самим можна було повернути статус "quo ante".

В окремих спірних дослідженнях соціальна педагогіка представлена маргінально, в основі якої лежить філософське обгрунтування П. Наторпа [5]. Невиявлений інтерес до положень забутих соціальних педагогів не суперечить загальній теоретико-історичній оцінці соціальної педагогіки, ідентифікованої як теоретичне повернення в історію педагогіки. Швидше за все слід розуміти й розрізняти полеміку у питаннях соціальної педагогіки як боротьбу з гербартіанством з точки зору освітньої та соціально-політичної перспективи. Такі прояви були неминучими. На той час не було жодного відкритого соціально-педагогічного аргументу проти гербартіанства. Як тільки появилися різкі випади соціальних педагогів проти гербартіанства, то не можна було приховати, що гербартіанці, зокрема К. Магер, наповнили зміст поняття “соціальна педагогіка" соціально-педагогічними теоріями, концепціями Ф.-В. Дьорпфельда, Й. Трюпе- pa, О. Вільманна. Зрештою, гербартіанці та їх опоненти не відділяють два ескізи соціальної педагогіки. Окрім того учні В. Райна - Г. Літц та К. Вількер залишили помітний слід в соціальній педагогіці. Обгрунтованим є припущення, що не було жодного розумно поясненого соціально-педагогічного аргументу проти гербартіанців. Водночас відмічаємо існування різних пояснень, педагогічних трактувань тлумачень теорій і концепцій, які об’єднували і гербартіанців, і негербартіанців. Слід розмежувати соціально-педагогічні дискусії щодо протиставлення гербартіанської та соціальної педагогіки.

У яких рамках соціалізувати освіту, наскільки близькою вона має бути суспільству, тобто формувати моральну людину - ці та інші питання заставили повернутися до педагогіки гербартіанства, оскільки різкої критики зазнав вплив на особистість не сім'“і чи школи, а вулиці, оточення. На часі було й інше запитання - хто нестиме відповідальність за особистість у суспільстві. Відповідь на нього ми можемо віднайти у Ф.-В. Дьорпфельда. Гербартіанець визначив чотирьох зацікавлених у навчанні та вихованні молоді (держава, церква, суспільство, сім'я). На його переконання, держава піклується про суспільно-політичне життя і культуру в цілому, суспільство гарантує освіту, церква має забезпечити етичне та релігійне виховання, а сім'я відповідальна за особистість в цілому. Його теорію Р. Ріссманн назвав консервативною. Відтак відповідь гербартіанців не забарилася. У “Журналі з філософії та педагогіки" вони обгрунтували ідеї Ф.-В. Дьорпфельда як основу теорії виховання.

О. Вільманн виступав за те, щоб відповідальність за освіту була покладена на католицьку церкву. Він зробив зауваження історії ідеалізму, що сучасність (кінець XIX ст.) слід порівняти із занепадом античного світу [14]. Він не виключав, що завданням освітнього процесу є забезпечення безперервного загального розвитку. Гербартіанець рекомендував не опускати із виду не лише суспільство, але і кожну окрему особистість, оскільки індивідуальні можливості $€$ віддзеркаленням соціальних можливостей [16]. Основою педагогіки О. Вільманна була організація соціальних спілок, які повинні були стати посередником між особистістю та отриманням нею освітніх і культурних благ.

У 1903 році Р. Ріссманн акцентував увагу на “Дидактиці” О. Вільманна, яка спровокувала наукову полеміку з проблематики соціальної педагогіки. Не визнання заслуг гербартіанця змусили Р. Ріссманна повернутися до його педагогічних ідей. Він неодно- 
значно натякав на тому, що О. Вільманну “боротьбі за Гербарта" виступив на його боці разом із В. Райном, К. Юстом та О. Флюгелем і дав відсіч соціальнопедагогічним нападкам, особливо П. Наторпа [9]. Гербартіанець прив'язав свою критику до того, що педагогіка П. Наторпа зорієнтована на філософію, а не педагогіку Канта. За О. Вільманном, моральне виховання грунтується на усвідомленні вихованцем певних правил іззовні, чого не було у Канта [13]. Саме у цьому гербартіанець помітив основну причину всіх розбіжностей.

Гербартіанець Й. Трюпер (1855 - 1921) звернувся до соціального питання у педагогіці. У 1890 році він опублікував у “Щорічнику спілки наукової педагогіки” свою працю “Виховання і суспільство”, у якій намагався закрити прогалини в основі педагогічної системи гербартіанців та встановити зв'язок школи,

\section{Література}

1. Bliedner A. Stoy, Karl Volkmar. In: Encyklopadisches Handbuch der Padagogik. Herausgegeben von W. Rein, Jena, zweiteAuflage, 8. Band, Langensalza, 1910.-1034 s.

2. Dollinger B. Die Padagogik der Sozialen Frage / Bernd Dollinger // (Sozial-)Padagogische Theorie vom Beginn des 19. Jahrhunderts bis zum Ende der Weimarer Republik. Wiesbaden : VS Verlag fur Sozialwissenschaften / GWV Fachverlage GmbH, 2006. - 481 s.

3. Muller C. Sozialpadagogik als Erziehung zur Demokratie/ C. Muller.-Bad Heilbrunn : Julius Klinkhardt, 2005. - 309 s.

4. Niemeyer C. Grundlinien historischer Sozialpodagogik: Traditionsbezuge, Reflexionen und ubergangene Sozialdiskurse / Christian Niemeyer, Wolfgang Schroer, Lothar Bohnisch (Hrsg.). - Weinheim; Munchen : Juventa Verlag, 1997. $-297 \mathrm{~s}$.

5. Oelkers Jurgen.Wilhelm Rein und die Konstruktion von „Reformpadagogik“. In: Rotraud Coriand / Michael Winkler (Hrsg.): Der Herbartianismus - Die vergessene Wissenschaftsgeschichte. - Weinheim, 1998. - $185 \mathrm{~s}$.

6. Rein Wilhelm. Padagogik in systematischer Darstellung/ W. Rein. -2 Bande. 1.Aufl. Langensalza, 1902.-529 s.

7. Rein W. (HG.) Encyklopadisches Handbuch der Padagogik/ Wilhelm Rein. - Band 1-7. [7 Bd.]. - Beyer \& Sohne, Langensalza, 1895.-6000 S. -2.Aufl. Langensalza, 1903-11.- виховання з суспільством, як і педагогіки із суспільними науками. Так, соціально-педагогічні ідеї Й. Трюпера, пов' язані з гербартіанством,були хронологічно поновлені П. Наторпом у соціальній педагогіці 3 огляду на неокантизм.

Висновки. Гербартіанці намагалися розв'язати питання виховання особистості з метою утвердження іï у суспільстві. Прогрес та недоліки суспільного життя змусили педагогіку перебрати на себе функції виховного характеру, по-перше, обгрунтоване в епоху Ренесансу право особистості та, по-друге, недоліки у роботі соціальних інстанцій повинні були сприяти вихованню повноцінного громадянина. Гербартіанці заявляли, що, з одного боку, виховання базувалося на релігії, моралі, національності, сім'ї, а з іншого німецьке виховання вимагало сформованої особистості, власне як і гербартіанська педагогіка.

10 Bande.-Band 8. -937 S.; Band 9.-911 S.; Band 10.-1026 s.

8. Rein W. 1924: Marx oder Herbart /Wilhelm Rein. - Harz/ Leipzig: Langensalza, 1924.-20 s.

9. Rissmann R. Sozialpadagogik / R. Rissmann // Volksschulreform. Herbartianismus, Sozialpadagogik, Personlichkeitsbildung. - Leipzig, 1903.-439s.

10. Schulze-Delitzsch F. H. Kapitel zu einem deutschen Arbeiterkatechismus / F. H. Schulze-Delitzsch. - In: ders.: Schriften und Reden. Bd. 2. - Berlin, 1863/1910. - S. 26-173.

11. Schwenk B. Das Herbartverstandnis der Herbartianer. Gottinger Studien zur Padagogik. - Weinheim, 1963. - 176 s.

12. ZillerT. Materialien zur speziellen Padagogik/Tuiskon Ziller.-Dresden : Bley\&Dammerer, 1886.-296s.

13. Willmann O. Die soziale Aufgabe der hoheren Schulen: Vortrag gehalten in der Gehe-Stiftung zu Dreden am 7. Februar 1891 / O. Willmann. - Braunschuweig: F. Vieweg, 1891.-24 s.

14. Willmann O. Die Volksschule und die soziale Frage / Otto Willmann // Samtliche Werke, B.7., Aalen. - 1982. - S. 460 468.

15. Willmann O. Neukantianismus gegen Herbarts Padagogik / Otto Willmann // Zeitschrift fur Philosophie und Padagogik, 6. Jg. - 1895.-S. $103-108$.

16. Willmann O. Sozialpadagogik / Otto Willmann//Lexikon der Padagogik. - Freiburg i.Br., Bd. 4, 1915.-S. 1107-1111. 